in reducible cytochrome $b$. Brain 100:617

32. Morgan-Hughes JA, Darveniza P, Landon DN, Land JM, Clark JB 1979 A mitochondrial myopathy with a deficiency of respiratory chain NADH-CoQ reductase activity. J Neurol Sci 43:27

33. Morgan-Hughes JA, Hayes DJ, Clark JB, Landon DN, Swash M, Stark RJ, Rudge P 1982 Mitochondrial encephalomyopathies. Biochemical studies in two cases revealing defects in the respiratory chain. Brain 105:553

34. Nachlas MM, Tsou K-C, De Souza E, Cheng C-S, Seligman AM 1957 Cytochemical demonstration of succinic dehydrogenase by the use of a new $p$ nitrophenyl substituted ditetrazole. J Histochem Cytochem 5:420

35. Pettersen JE, Jellum E, Eldjarn L 1972 The occurrence of adipic and suberic acid in urine from ketotic patients. Clin Chim Acta 38:17

36. Rieske JS 1976 Composition, structure and function of complex III of the respiratory chain. Biochim Biophys Acta 456:195

37. Robinson BH, Sherwood WG 1975 Pyruvate dehydrogenase phosphatase deficiency: a cause of congenital chronic lactic acidosis in infancy. Pediatr Res 9:935

38. Robinson BH, Taylor J, Sherwood WG 1977 Deficiency of dihydrolipoyl dehydrogenase (a component of the pyruvate and $\alpha$-ketoglutarate dehydrogenase complexes): a cause of congenital chronic lactic acidosis in infancy. Pediatr Res. 11:1198

39. Saudubray JM, Marsac C, Charpentier C, Cathelineau L, Beeson Leaud M, Leroux JP 1976 Neonatal congenital lactic acidosis with pyruvate carboxylase deficiency in two siblings. Acta Paediatr Scand 65:717

40. Senior B, Jungas RJ 1974 A disorder resulting from an enzymatic defect of the respiratory chain. Pediatr Res 8:438a

41. Sottocasa GL, Kuylenstierna B, Ernster L, Bergstrand A 1967 An electrontransport system associated with the outer membrane of liver mitochondria. A biochemical and morphological study. J Cell Biol 32:415

42. Spiro AJ, Moore CL, Prineas JW, Strasberg PM, Rapin I 1970 A cytochrome- related inherited disorder of the nervous system and muscle. Arch Neurol $23: 103$

43. Stansbie D, Dormer RL, Hughes IA, Minchom PE, Hendry GAF, Jones OTG, Cross AR, Sherratt HSA, Turnbull DM, Johnson MA 1982 Mitochondrial myopathy with skeletal muscle cytochrome oxidase deficiency. J Inher Metab Dis 5:27 (Suppl 1)

44. Stiggall DL, Galante YM, Hatefi Y 1979 Preparation and properties of complex V. Methods Enzymol 55:308

45. Strömme JH, Borud O, Moe PJ 1976 Fatal lactic acidosis in a newborn attributable to a congenital defect of pyruvate dehydrogenase. Pediatr Res 10:60

46. Towbin H, Staehelin T, Gordon J 1979 Electrophoretic transfer of proteins from polyacrylamide gels to nitrocellulose sheets: procedure and some applications. Proc Natl Acad Sci 76:4350

47. Van Biervliet JPGM, Bruinvis L, Ketting D, De Bree PK, van der Heiden C, Wadman SK, Willems JL, Bookelman H, Van Haelst U, Monnens LAH 1977 Hereditary mitochondrial myopathy with lactic acidemia, a DeToniFanconi-Debré syndrome, and a defective respiratory chain in voluntary striated muscles. Pediatr Res 11:1088

48. Van Biervliet JPGM, Bruinvis L, van der Heiden C, Ketting D, Wadman SK. Willems JL, Monnens LAH 1977 Report of a patient with severe, chronic lactic acidaemia and pyruvate carboxylase deficiency. Dev Med Child Neurol 19:392

49. Willems JL, Monnens LAH, Trijbels JMF, Veerkamp JH, Meyer AEFH, van Dam K, van Haelst U 1977 Leigh's encephalomyelopathy in a patient with cytochrome $c$ oxidase deficiency in muscle tissue. Pediatrics 60:850

50. Williamson DH, Lund P, Krebs HA 1967 The redox state of free nicotinamideadenine dinucleotide in the cytoplasm and mitochondria of rat liver. Biochem J 103:514

\title{
A Monoclonal Antibody Recognizes Structural Variation in Cystic Fibrosis $\alpha_{2}$-Macroglobulin
}

\author{
KENDRA B. EAGER AND ROGER H. KENNETT \\ Department of Human Genetics, University of Pennsylvania School of Medicine, \\ Philadelphia, Pennsylvania 19104
}

\section{Summary}

$\alpha_{2}$-Macroglobulin $\left(\alpha_{2} \mathbf{M}\right)$ is a major plasma protease inhibitor that has been studied because of its suggested role in the pathology of cystic fibrosis (CF). A panel of monoclonal antibodies specific for human $\alpha_{2} \mathrm{M}$ were produced and screened for their ability to bind to a number of human $\alpha_{2} M$ samples. We have used these antibodies to characterize individual antigenic sites in this protein. $\alpha_{2} M$ was purified from plasma by polyethylene glycol precipitation followed by zinc chelate chromatography. A total of $23 \alpha_{2} \mathrm{M}$ samples in the native configuration, as well as the nucleophile-treated configuration, were screened by the panel of 18 monoclonal antibodies in an enzyme-linked immunosorbent assay procedure. Five of the samples tested were from individuals with cystic fibrosis. $\alpha_{2} \mathrm{M}$ from family members of two of these patients was subsequently tested for reactivity with the monoclonal antibodies. One antibody, SAM94, exhibited a significant difference in binding to $\alpha_{2} \mathrm{M}$ obtained from $\mathrm{CF}$ patients as compared with control individuals. This difference was particu-

Received November 4, 1983; accepted February 7, 1984

Reprint requests may be addressed to Kendra B. Eager, The Wistar Institute, 36th and Spruce Streets, Philadelphia, PA 19104.

This work was supported by NSF Grant PCM-26757 and USPHS Grant CA24263. larly apparent in the binding of SAM94 to the nucleophile-treated CF $\alpha_{2}$ M; SAM94 showed significantly reduced binding to four of five unrelated CF individuals $(p<0.005)$ and three of four cystic fibrosis obligate heterozygotes $(p<0.005)$.

\section{Abbreviations}

$\alpha_{2} \mathrm{M}, \alpha_{2}$-macroglobulin

CF, cystic fibrosis

ELISA, enzyme-linked immunosorbent assay

PEG, polyethylene glycol

PBS, phosphate-buffered saline

PMSF, phenylmethylsulfonyl fluoride

SBTI, soybean trypsin inhibitor

TEMED, $N, N, N^{\prime}, N^{\prime}$-tetramethylethylenediamine

$\alpha_{2} \mathrm{M}$ is a plasma glycoprotein that functions in the inhibition and elimination of proteases from the plasma (16). The molecule, composed of four subunit chains of 185,000 molecular weight (11), binds irreversibly to the active form of proteases, changing the conformation of $\alpha_{2} \mathrm{M}$ and thereby trapping the enzyme (2). A similar conformational change can be mimicked by treatment 
of $\alpha_{2} \mathrm{M}$ with nucleophilic compounds such as methylamine (27). These altered molecules are cleared from the circulation in the same manner as the protease- $\alpha_{2} \mathrm{M}$ complexes (12). The modified form shows a greater electrophoretic mobility on polyacrylamide gels than the native form and is often termed "fast $\alpha_{2} \mathrm{M}$."

Cystic fibrosis has been studied for many years although no biochemical or structural defect has been established (28). The probable involvement of $\alpha_{2} \mathrm{M}$ in the pathology of cystic fibrosis has been suggested by several groups based upon their work on isoelectric focusing of serum samples (29) and immunological and biochemical examination of protease- $\alpha_{2} \mathrm{M}$ complexes (2225 ). However, recent reports have failed to confirm differences in structure and protease binding capabilities of cystic fibrosis and normal $\alpha_{2} \mathrm{M}(5,7,8,19)$.

Since the report of continuously growing cell lines producing homogeneous antibodies in 1975 (14), these monoclonal antibodies have provided a way to study the structure of proteins that was not possible with conventional antisera. Single determinants on a molecule can be examined with these reagents because of their unique specificities. We have produced monoclonal antibodies to human $\alpha_{2} \mathrm{M}$ (9) and have used these antibodies to examine $\alpha_{2} \mathrm{M}$ purified from plasma samples. In this report, we discuss our findings using a panel of anti-human $\alpha_{2} \mathrm{M}$ monoclonal antibodies in an enzyme-linked immunoassay to examine a number of purified human plasma $\alpha_{2} \mathrm{M}$ samples.

\section{METHODS}

Materials and antisera. All chemicals used were reagent grade unless otherwise indicated. Acrylamide, bis-acrylamide, and TEMED were obtained from Bio-Rad Laboratories, Richmond, CA. PEG 1000 used for fusions was from J.T. Baker Chemical Co, Phillipsburg, NJ. Bovine serum albumin determined to be peroxidase free) was from Calbiochem, San Diego, CA. Purified human immunoglobulin was obtained from Cappel Laboratories, Cochranville, PA. Zinc chelate-Sepharose 4B resin was kindly provided by Dr. J. Kaplan, University of Utah, Salt Lake City, UT. PMSF, o-phenylene diamine, polyethylene glycol 6000 , SBTI (Type 1S), Tween 80 and all other chemicals not mentioned above were obtained from Sigma Chemical Co, St. Louis, MO.

Polystyrene 96-well microtiter plates (Immunlon) were from Dynatech Laboratories, Alexandria, VA.

Peroxidase conjugated sheep anti-mouse immunoglobulin and rabbit anti-rat immunoglobulin were obtained from Cappel Laboratories.

Plasma. Fresh plasma from individuals with cystic fibrosis and heterozygotes was obtained by Dr. D. Holsclaw from patients and family members seen at the Cystic Fibrosis Clinic at Hahnemann Hospital and Medical College, Philadelphia, PA. Normal plasma was supplied by the Tissue Typing Laboratory of the Hospital of the University of Pennsylvania and the Blood Bank of Children's Hospital of Philadelphia. Blood was collected in vacutainers containing $15 \%$ EDTA. Plasma was separated by centrifugation, and PMSF was added to a final concentration of $10 \mathrm{mM}$. Sodium azide was added to $0.1 \%$. The preparation was frozen at $-70^{\circ} \mathrm{C}$.

Isolation and purification of $\alpha_{2} M . \alpha_{2} \mathrm{M}$ was purified from plasma by polyethylene glycol precipitation and zinc chelate chromatography according to the methods described by Barrett et al. (1) and Kurecki et al. (15). Plasma samples $(5-50 \mathrm{ml})$, to which SBTI was added $(0.1 \mathrm{mg} / \mathrm{ml})$, were rapidly thawed and 0.28 volumes of $25 \%(\mathrm{~W} / \mathrm{V}) \mathrm{PEG} 6000, \mathrm{pH} 6.5$ were mixed with each sample. The solution was kept at room temperature for 30 min then centrifuged at $4^{\circ} \mathrm{C}$ at $10,000 \times g$ for $30 \mathrm{~min} .0 .72$ volumes of $25 \%$ PEG was added to the supernatant and allowed to sit at room temperature for $30 \mathrm{~min}$. The plasma-PEG solution was centrifuged as described above. The precipitate was dissolved in $20 \mathrm{mM}$ sodium phosphate, $\mathrm{pH} 6.4$ and dialyzed overnight against distilled water.
The dialysate was applied to a $1.0 \times 11 \mathrm{~cm}$ column of Sepharose $4 \mathrm{~B}$ which had been treated with zinc chloride. The column was washed with several column volumes of $0.2 \mathrm{M}$ sodium phosphate, $0.15 \mathrm{M} \mathrm{NaCl}, \mathrm{pH} 6.0$, and the $\alpha_{2} \mathrm{M}$ eluted with 0.02 $\mathrm{M}$ sodium cacodylate, $0.15 \mathrm{M} \mathrm{NaCl}, \mathrm{pH} 5.0$ (15). The optical density of each fraction was determined at $280 \mathrm{~nm}$ and samples containing sufficient quantities of protein were pooled. Concentration of $\alpha_{2} \mathrm{M}$ was calculated using an extinction coefficient of 8.93 (31). Regeneration of the column was accomplished by washing with $0.05 \mathrm{M}$ EDTA, $0.5 \mathrm{M} \mathrm{NaCl}, \mathrm{pH} 7.0$ followed by equilibration of the resin with zinc chloride $(3 \mathrm{mg} / \mathrm{ml}, \mathrm{pH} 6.0)$ and washed with $0.25 \mathrm{M}$ sodium acetate, $0.15 \mathrm{M} \mathrm{NaCl}, \mathrm{pH}$ 5.0. Pooled samples of $\alpha_{2} \mathrm{M}$ were dialyzed against PBS, pH 7.2 and stored in glass tubes at $4^{\circ} \mathrm{C}$ with $0.1 \%$ sodium azide.

Treatment of $\alpha_{2} M$ with methylamine. Purified $\alpha_{2} \mathrm{M}$ that was modified by reaction with methylamine was initially dialyzed against several changes of $0.05 \mathrm{M}$ Tris $\mathrm{HCl}, \mathrm{pH} 8.0$ for $48 \mathrm{~h}$ or until the $\mathrm{pH}$ of the $\alpha_{2} \mathrm{M}$ solution was 8.0 . Methylamine was added to a final concentration of $200 \mathrm{mM}$ and the solution incubated for $2 \mathrm{~h}$ at $37^{\circ} \mathrm{C}$. The modified $\alpha_{2} \mathrm{M}$ was stored at $4^{\circ} \mathrm{C}$ with $0.1 \%$ sodium azide.

Electrophoresis of $\alpha_{2} M$ forms. $\alpha_{2} \mathrm{M}$ purified by zinc chelate chromatography and samples modified by treatment with methylamine were examined by polyacrylamide gel electrophoresis. Samples dissolved in sample buffer containing $0.16 \mathrm{M}$ Tris, $\mathrm{pH}$ $8.8,10.7 \%$ glycerol and $0.01 \%$ bromphenol blue were applied to a $5-15 \%$ discontinuous nondenaturing gradient gel as described by Zais and Roberts (31) and run at $200 \mathrm{~V}$ for $3 \mathrm{~h}$. The gel was stained for protein with Coomassie brilliant blue.

Production of anti-human $\alpha_{2} M$ hybridomas. Hybridomas were produced from the fusion of spleen cells from mice and rats immunized with purified human $\alpha_{2} \mathrm{M}$ and $\mathrm{Sp} 2 / 0-\mathrm{Ag} 14$, a nonsecreting mouse myeloma (26). The method of immunization, maintenance of cells, and specificity of antibodies are described elsewhere $(9,13)$.

Enzyme-linked immunosorbent assay. The source of monoclonal antibodies was cell culture supernatant removed from cells that were in mid-log phase. Supernatant was stored at $4^{\circ} \mathrm{C}$ with $0.1 \%$ sodium azide. Antisera used as the positive control in these assays were obtained from bleeding of the immunized animals at the time of sacrifice prior to the removal of the spleen for fusion with the myeloma cells. The ELISA procedure was performed as described previously (9) although in this case purified $\alpha_{2} \mathrm{M}$ was used.

Purified $\alpha_{2} \mathrm{M}$ diluted in 0.05 sodium carbonate, $\mathrm{pH} 9.8$ was added to the wells of a distilled water rinsed 96-well polystyrene plate $\left(0.1 \mu \mathrm{g} \alpha_{2} \mathrm{M}\right.$ in $50 \mu \mathrm{l} /$ well $)$. The protein was incubated for $18 \mathrm{~h}$ at $4^{\circ} \mathrm{C}$ and then rinsed twice with a solution of $0.05 \%$ Tween 80 in PBS, pH 7.2 (TwPBS). Monoclonal antibodies were added and incubated for $2 \mathrm{~h}$ at room temperature. Following $2-$ 4 washes of TwPBS, peroxidase conjugated antisera, mixed with an equal volume of human immunoglobulin and preincubated for $18 \mathrm{~h}$ at $4^{\circ} \mathrm{C}$, was diluted in TwPBS containing an additional $2 \% \mathrm{NaCl}, 0.05 \mathrm{M}$ EDTA and $0.1 \%$ bovine serum albumin (peroxidase free), added to each well of the polystyrene plate and incubated for $2 \mathrm{~h}$. Following the incubation, the plates were washed 3-5 times with TwPBS. $150 \mu$ l of substrate solution (5.5 $\mathrm{mM}$ o-phenylene diamine and $12 \mathrm{mM}$ hydrogen peroxide in 0.1 $\mathrm{M}$ sodium citrate buffer, $\mathrm{pH} 4.5$ ) was added to each well of the plate and incubated for $15 \mathrm{~min}$ at room temperature. The colorimetric reaction was stopped by the addition of $25 \mu \mathrm{l}$ of 0.1 $M$ sodium fluoride and the optical densities determined at 450 $\mathrm{nm}$ using a Multiscan spectrophotometer (Flow Laboratories, McLean, VA).

\section{RESULTS}

Preparation of $\alpha_{2} M$ for enzyme-linked immunosorbent assay. Fresh plasma samples from presumably normal volunteers and patients with cystic fibrosis (mild to moderate severity of disease) 
were the sources of $\alpha_{2} \mathrm{M}$ used in these experiments. The method for purification using polyethylene glycol precipitation followed by passage of the $\alpha_{2} \mathrm{M}$ containing fraction over a zinc chelate complexed Sepharose column provided us with $\alpha_{2} \mathrm{M}$ in the native form. The elution profile from the zinc chelate column of polyethylene glycol purified $\alpha_{2} \mathrm{M}$ is shown in Figure 1. The first peak consists of unbound plasma proteins whereas the second peak is column purified $\alpha_{2} \mathrm{M}$ which was pooled and dialyzed against phosphate buffered saline. The use of fresh plasma yields product which has been shown to contain $\alpha_{2} \mathrm{M}$ in primarily the native form. The conversion of native, electrophoretically "slow" $\alpha_{2} \mathrm{M}$ by treatment with $200 \mathrm{mM}$ methylamine to the electrophoretic "fast" form is shown to be nearly complete as seen in Figure 2. The electrophoresis of samples of untreated and chemically modified $\alpha_{2} \mathrm{M}$ on a $5-15 \%$ discontinuous gradient polyacrylamide gel demonstrates that a high percentage of $\alpha_{2} \mathrm{M}$ isolated by the PEG precipitation and zinc chelate chromatography is in the electrophoretically slow form (Fig. 2, lanes 1, 3, 5, 7). In lanes 2, 4, and 6, one notices an increase in electrophoretic mobility after treatment with methylamine of the same $\alpha_{2} \mathrm{M}$ sample from lanes 3,5 , and 7 . The conversion to the fast form is nearly complete.

Assay using monoclonal antibodies to analyze human $\alpha_{2} M$. Monoclonal antibodies have been produced against human $\alpha-2$ macroglobulin as described elsewhere (9). These rat and mouse monoclonal antibodies have been shown to react with $\alpha_{2} \mathrm{M}$ in both the native and methylamine-treated forms. A panel of 18 monoclonal antibodies reacting with human $\alpha_{2} \mathrm{M}$ were selected to analyze the structure of a number of $\alpha_{2} \mathrm{M}$ samples. $\alpha_{2} \mathrm{M}$ from the purification described above was quantitated by determination of the absorbance of the solution at $280 \mathrm{~nm}$.

The levels of reaction of the monoclonal antibodies with the $\alpha_{2} \mathrm{M}$ samples were determined by the use of an enzyme-linked immunoassay to quantitate the antibody binding to a given concentration of the purified antigen. Plasma $\alpha_{2} \mathrm{M}$ in both the native and methylamine-treated forms (slow and fast forms, respectively) were screened with the panel of monoclonal antibodies which had been selected on the basis of stability of expression and affinity of antibody. For each $\alpha_{2} \mathrm{M}$ sample purified, $0.1 \mu \mathrm{g}$ of $\alpha_{2} \mathrm{M}$ was applied per well of a polystyrene plate; duplicate determinations for each antibody were performed on at least three independent occasions. Absorbance values were normalized for each antibody in the individual assays according to the equation $V=(A-B) /(C-B)$ where $A$ is the absorbance value of the monoclonal antibody binding to sample $n, B$ is the

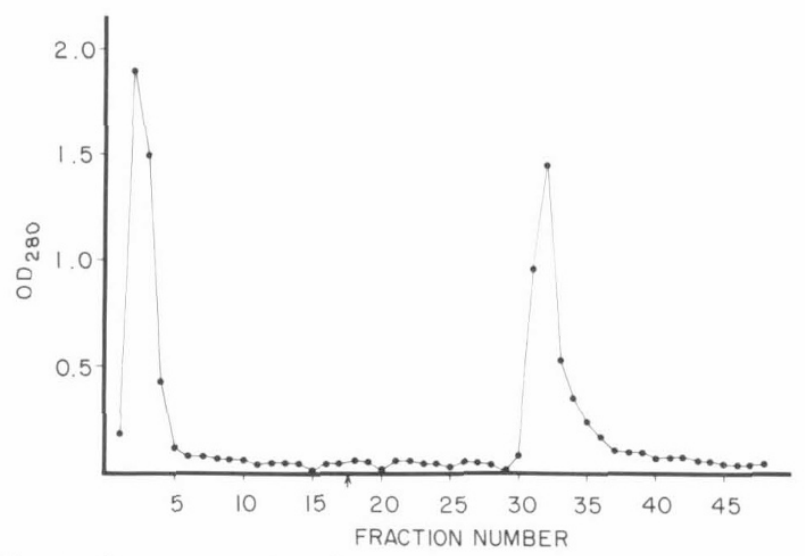

Fig. 1. Chromatography of $\alpha_{2} \mathrm{M}$ on zinc chelate column. Dialyzed $\alpha_{2} \mathrm{M}$ purified from $6 \mathrm{ml}$ of plasma was charged on a $(1.0 \times 11 \mathrm{~cm})$ zinc chelate-Sepharose column equilibrated with $0.02 \mathrm{M}$ sodium phosphate, $0.15 \mathrm{M}$ sodium chloride, $\mathrm{pH} 6.0$, at a flow rate of $100 \mathrm{ml} / \mathrm{h}$. Elution was begun with the same buffer at $50 \mathrm{ml} / \mathrm{h}$ and $9.2 \mathrm{ml}$ fractions were collected. At fraction 18 , the buffer was changed to $0.02 \mathrm{M}$ sodium cacodylate, $0.15 \mathrm{M}$ sodium chloride, $\mathrm{pH} 5.0$ and $0.9 \mathrm{ml}$ fractions were collected. Fractions 31-34 were pooled, dialyzed against PBS and stored with azide.

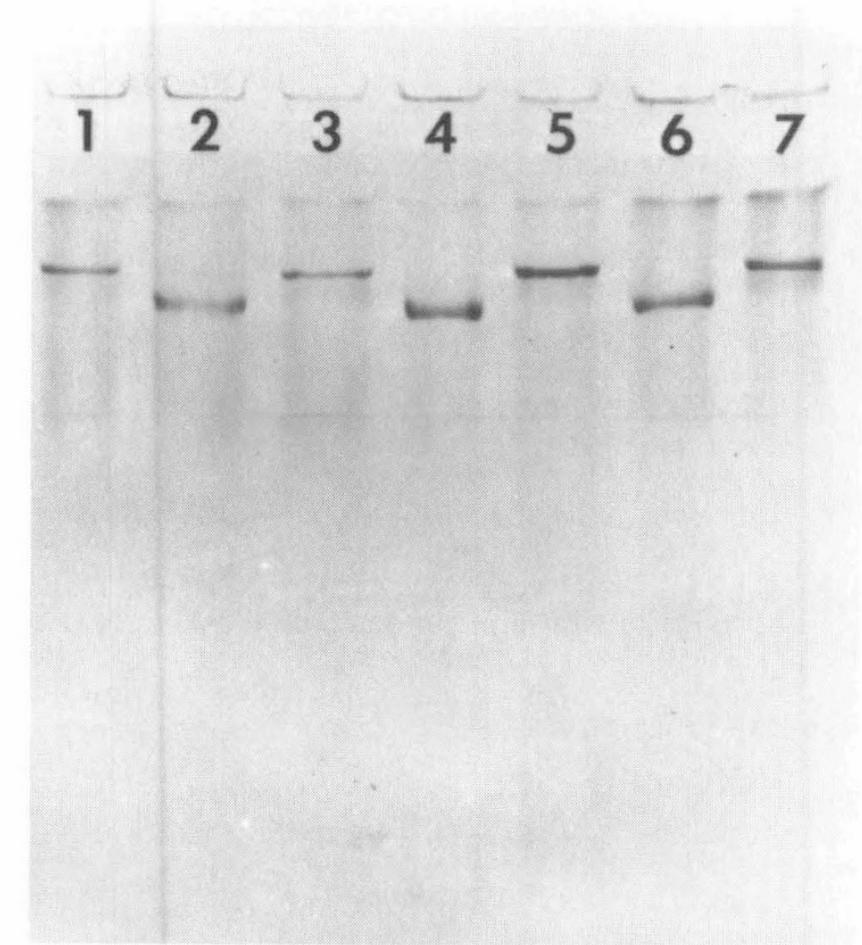

Fig. 2. Changes in electrophoretic mobility of $\alpha_{2} \mathrm{M}$ resulting from treatment with methylamine. Human $\alpha_{2} \mathrm{M}$ in $0.05 \mathrm{M}$ Tris $\mathrm{HCl}, \mathrm{pH} 8.0$ was treated with $200 \mathrm{mM}$ methylamine for $1 \mathrm{~h}$ at $37^{\circ} \mathrm{C}$. Samples of human $\alpha_{2} \mathrm{M}$ were examined by acrylamide gradient pore gel electrophoresis. The gel was stained with Coomassie brilliant blue R-250. Lane 1 is Sample $12 \alpha_{2} \mathrm{M}$ untreated; lane 2 Sample $11 \alpha_{2} \mathrm{M}$ treated with methylamine; lane 3 Sample 11 untreated; lane 4 Sample 10 treated; lane 5 Sample 10 untreated; lane 6 Sample 9 treated, and lane 7 Sample 9 untreated.

absorbance value of nonspecific binding of Sp2/0-Ag14 supernatant to sample $n$, and $C$ is the absorbance value of the standard anti-human $\alpha_{2} \mathrm{M}$ sera obtained from the immunized animals. These normalized values are termed binding ratios. The levels of binding of standard antisera to individual $\alpha_{2} \mathrm{M}$ samples were equivalent.

Reactivity patterns. We show in this paper the results of the binding of three antibodies to the group of $\alpha_{2} \mathrm{M}$ samples. The two antibodies SAR 87 and SAM167 were chosen for discussion here on the basis of their reactivity patterns and are representative of all except one of the 18 antibodies with respect to the reactivities towards cystic fibrosis and control $\alpha_{2} \mathrm{M}$ samples. SAM94 exhibits a reactivity pattern unlike the other antibodies. The binding ratios for each of the three antibodies were calculated for duplicate determinations in three independent assays. The mean and standard deviation of the binding ratios for each antibody and each $\alpha_{2} \mathrm{M}$ sample (both forms) were calculated and are listed in Table 1. Individuals 4, 5, 18, 19, and 20 are unrelated individuals with cystic fibrosis. Plasma $\alpha_{2} \mathrm{M}$ of individuals from the families of individuals 4 and 19 were also tested. The pedigrees of these two families are shown in Figure 3. $\alpha_{2} \mathrm{M}$ samples 8 and 11 are from the same individual although blood was drawn at different times and processed separately. The same situation is true for samples 14 and 15 . The reproducibility of the purification procedure, as well as the enzyme-linked immunoassay, is demonstrated by comparison of the binding ratios given in Table 1 for these $\alpha_{2} \mathrm{M}$ samples.

SAR87 is a rat monoclonal antibody which reacts similarly with both the slow form and fast form of $\alpha_{2} \mathrm{M}$ (Table 1; Fig. 4). 
Table 1. Mean binding ratios for the reactions of three monoclonal antibodies (SAR87, SAM94, SAM167) to human $\alpha_{2} M$ samples in the native and chemically treated forms*

\begin{tabular}{|c|c|c|c|c|c|c|c|}
\hline \multirow{2}{*}{$\begin{array}{l}\text { Genetic } \\
\text { status }\end{array}$} & \multirow{2}{*}{$\begin{array}{c}\text { Sample } \\
n\end{array}$} & \multicolumn{2}{|c|}{ SAR87 } & \multicolumn{2}{|c|}{ SAM94 } & \multicolumn{2}{|c|}{ SAM167 } \\
\hline & & Slow & Fast & Slow & Fast & Slow & Fast \\
\hline $\mathrm{N}$ & 2 & $0.175 \pm 0.069$ & $0.194 \pm 0.083$ & $1.707 \pm 0.035$ & $1.331 \pm 0.033$ & $0.055 \pm 0.019$ & $0.060 \pm 0.032$ \\
\hline $\mathrm{N}$ & 3 & $0.264 \pm 0.085$ & $0.295 \pm 0.035$ & $1.156 \pm 0.122$ & $1.154 \pm 0.128$ & $0.073 \pm 0.012$ & $0.120 \pm 0.033$ \\
\hline $\mathrm{N}$ & 6 & $0.203 \pm 0.036$ & $0.214 \pm 0.053$ & $1.124 \pm 0.180$ & $0.894 \pm 0.072$ & $0.134 \pm 0.023$ & $0.163 \pm 0.031$ \\
\hline $\mathrm{N}$ & 7 & $0.198 \pm 0.040$ & $0.170 \pm 0.027$ & $0.869 \pm 0.103$ & $0.903 \pm 0.068$ & $0.143 \pm 0.036$ & $0.182 \pm 0.043$ \\
\hline $\mathrm{N}$ & $8 \S$ & $0.178 \pm 0.057$ & $0.163 \pm 0.040$ & $0.942 \pm 0.070$ & $0.818 \pm 0.049$ & $0.184 \pm 0.049$ & $0.187 \pm 0.027$ \\
\hline $\mathrm{N}$ & 9 & $0.200 \pm 0.072$ & $0.204 \pm 0.048$ & $1.036 \pm 0.104$ & $0.960 \pm 0.029$ & $0.193 \pm 0.044$ & $0.260 \pm 0.059$ \\
\hline $\mathrm{N}$ & 10 & $0.209 \pm 0.021$ & $0.157 \pm 0.019$ & $0.923 \pm 0.044$ & $0.853 \pm 0.093$ & $0.324 \pm 0.042$ & $0.339 \pm 0.028$ \\
\hline $\mathrm{N}$ & $11 \S$ & $0.144 \pm 0.030$ & $0.116 \pm 0.022$ & $1.008 \pm 0.068$ & $0.914 \pm 0.054$ & $0.213 \pm 0.025$ & $0.158 \pm 0.048$ \\
\hline $\mathrm{N}$ & 12 & $0.245 \pm 0.038$ & $0.102 \pm 0.056$ & $1.077 \pm 0.152$ & $0.912 \pm 0.094$ & $0.107 \pm 0.033$ & $0.097 \pm 0.024$ \\
\hline $\mathrm{N}$ & 13 & $0.139 \pm 0.036$ & $0.116 \pm 0.033$ & $1.185 \pm 0.205$ & $0.880 \pm 0.120$ & $0.174 \pm 0.040$ & $0.141 \pm 0.052$ \\
\hline $\mathrm{N}$ & $14 \pi$ & $0.213 \pm 0.029$ & $0.113 \pm 0.056$ & $0.902 \pm 0.057$ & $0.824 \pm 0.150$ & $0.261 \pm 0.101$ & $0.174 \pm 0.053$ \\
\hline $\mathrm{N}$ & $15 \pi$ & $0.182 \pm 0.050$ & $0.144 \pm 0.029$ & $0.958 \pm 0.236$ & $0.781 \pm 0.074$ & $0.294 \pm 0.078$ & $0.279 \pm 0.028$ \\
\hline $\mathrm{N}$ & 16 & $0.264 \pm 0.055$ & $0.156 \pm 0.039$ & $0.896 \pm 0.119$ & $0.789 \pm 0.092$ & $0.287 \pm 0.078$ & $0.339 \pm 0.034$ \\
\hline $\mathrm{N}$ & 17 & $0.138 \pm 0.053$ & $0.170 \pm 0.060$ & $0.904 \pm 0.063$ & $0.908 \pm 0.094$ & $0.164 \pm 0.031$ & $0.195 \pm 0.017$ \\
\hline $\mathrm{CF}$ & 4 & $0.165 \pm 0.075$ & $0.252 \pm 0.033$ & $0.489 \pm 0.056$ & $0.313 \pm 0.018$ & $0.402 \pm 0.028$ & $0.576 \pm 0.175$ \\
\hline $\mathrm{CF}$ & 5 & $0.236 \pm 0.013$ & $0.130 \pm 0.031$ & $1.097 \pm 0.031$ & $0.676 \pm 0.069$ & $0.205 \pm 0.072$ & $0.195 \pm 0.034$ \\
\hline $\mathrm{CF}$ & 18 & $0.172 \pm 0.023$ & $0.155 \pm 0.054$ & $0.818 \pm 0.093$ & $0.851 \pm 0.067$ & $0.174 \pm 0.030$ & $0.199 \pm 0.020$ \\
\hline $\mathrm{CF}$ & 19 & $0.289 \pm 0.045$ & $0.192 \pm 0.016$ & $0.715 \pm 0.118$ & $0.601 \pm 0.066$ & $0.202 \pm 0.047$ & $0.280 \pm 0.032$ \\
\hline $\mathrm{CF}$ & 20 & $0.129 \pm 0.048$ & $0.137 \pm 0.017$ & $0.646 \pm 0.099$ & $0.439 \pm 0.048$ & $0.370 \pm 0.032$ & $0.400 \pm 0.029$ \\
\hline $\mathrm{CF}$ & 22 & $0.226 \pm 0.042$ & $0.245 \pm 0.027$ & $0.814 \pm 0.039$ & $0.636 \pm 0.030$ & $0.133 \pm 0.030$ & $0.163 \pm 0.022$ \\
\hline $\mathrm{CF}$ & 26 & $0.364 \pm 0.078$ & $0.338 \pm 0.080$ & $0.967 \pm 0.128$ & $0.714 \pm 0.078$ & $0.136 \pm 0.049$ & $0.155 \pm 0.022$ \\
\hline $\mathrm{CFH}$ & 21 & $0.391 \pm 0.034$ & $0.329 \pm 0.043$ & $0.963 \pm 0.024$ & $0.796 \pm 0.019$ & $0.275 \pm 0.017$ & $0.260 \pm 0.033$ \\
\hline ?‡ & 23 & $0.211 \pm 0.068$ & $0.176 \pm 0.044$ & $0.719 \pm 0.092$ & $0.603 \pm 0.092$ & $0.195 \pm 0.031$ & $0.171 \pm 0.036$ \\
\hline $\mathrm{CFH}$ & 24 & $0.416 \pm 0.064$ & $0.291 \pm 0.063$ & $0.712 \pm 0.065$ & $0.466 \pm 0.038$ & $0.380 \pm 0.060$ & $0.380 \pm 0.029$ \\
\hline ? & 25 & $0.422 \pm 0.093$ & $0.338 \pm 0.100$ & $1.026 \pm 0.080$ & $0.946 \pm 0.078$ & $0.158 \pm 0.046$ & $0.156 \pm 0.028$ \\
\hline $\mathrm{CFH}$ & 27 & $0.440 \pm 0.057$ & $0.366 \pm 0.096$ & $0.698 \pm 0.151$ & $0.563 \pm 0.205$ & $0.301 \pm 0.121$ & $0.299 \pm 0.046$ \\
\hline CFH & 28 & $0.299 \pm 0.106$ & $0.229 \pm 0.018$ & $0.577 \pm 0.121$ & $0.557 \pm 0.039$ & $0.248 \pm 0.079$ & $0.230 \pm 0.022$ \\
\hline
\end{tabular}

* Values shown are mean binding ratio $\pm \mathrm{SD}$.

$\dagger \mathrm{N}$, normal individual; $\mathrm{CFH}$, cystic fibrosis obligate heterozygote.

$\ddagger$ ?, unaffected sibling of $\mathrm{CF}$ patient, genetic status unconfirmed.

$\S 8,11$, same individual, blood drawn at different times.

ๆ 14,15 , same individual, blood drawn at different times.

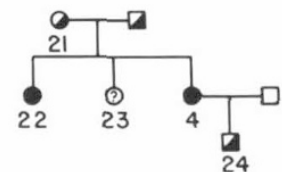

FAMILY I

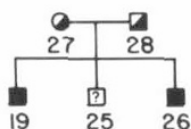

FAMILY II

Fig. 3. Pedigrees of families I and II. Solid figures represent individuals with $\mathrm{CF}$; half-filled figures represent obligate heterozygotes; figures with question marks indicate nonobligate heterozygotes but possibly carriers of the gene.

Antibody SAM167 is a mouse monoclonal antibody that also reacts similarly with both forms of $\alpha_{2} \mathrm{M}$ from the same individual although the binding ratios do not overlap as much as with SAR87. Antibody SAM94, although reacting with both forms, shows a very different pattern of binding to particular samples. SAM94 and SAM 167 are antibodies of the $\mathrm{IgG}_{1}$ isotype as determined by immunoprecipitation with class specific antisera.

The mean binding ratios for these three antibodies are shown in graphical form in Figure 4. In addition, the genetic status of the individuals is noted by a solid square for those individuals with $\mathrm{CF}$, half-filled squares for $\mathrm{CF}$ family members, and open squares for control individuals. Note the distribution of solid and half-filled squares. SAM94 (Fig. 4, panel C) shows a clustering of these samples at lower binding ratios in both forms of $\alpha_{2} \mathrm{M}$. With antibodies SAR87 and SAM167 (panels A and B, respectively), there is a random distribution of binding ratios from $\mathrm{CF}$ homozygotes and family members among the control individuals. Only with SAM94 is there a clustering of mean binding ratios from $\mathrm{CF}$ homozygotes and family members in both the

slow and fast forms of $\alpha_{2} \mathrm{M}$. When the standard deviations are considered, the binding of the samples from CF homozygotes and certain family members are clearly distinguished from the remainder of the samples. Figure 5, a replotting of the data in Figure 4, panel $\mathrm{C}$ of the antibody reaction with the fast form (methylamine-treated) of $\alpha_{2} \mathrm{M}$, more clearly distinguishes the differences in antibody reactivity to individual samples of $\alpha_{2} \mathrm{M}$. The unaffected obligate heterozygotes are marked by an asterisk.

The significance of the difference between the mean binding ratio for normal $\alpha_{2} \mathrm{M}$ samples (methylamine-treated) and the mean binding ratio for $\mathrm{CF}\left(\alpha_{2} \mathrm{M}\right.$ methylamine-treated) samples with antibody SAM94 was determined by a Student $t$ test. The difference between the 12 normal samples $(0.938 \pm 0.154$; mean $\pm \mathrm{SD})$ and the 5 unrelated CF samples $(0.576 \pm 0.209)$ is statistically highly significant $(p<0.005)(t=4.02)$. Also, comparison of the means of the four obligate heterozygote samples $(0.595 \pm 0.141)$ is significantly different from that of the normal samples at the $p<0.005$ level of significance $(t=3.94)$. However, a $t$ test comparing $\mathrm{CF}$ and obligate heterozygotes binding ratios does not show any significant difference between these two groups $(t=-0.155)$.

Although the difference in the binding ratios of antibody SAM94 to CF and normal $\alpha_{2} \mathrm{M}$ is based only on a limited number of samples, the genetic status of unaffected individuals who are not obligate heterozygotes can be inferred using the binding ratios. In family I, unaffected individual 23 has a $66 \%$ probability of carrying the gene for cystic fibrosis. The binding ratio of SAM 94 to methylamine-treated $\alpha_{2} \mathrm{M}$ from this individual is in the range observed for $\mathrm{CF}$ obligate heterozygotes and homozygotes. On the other hand, methylamine-treated $\alpha_{2} \mathrm{M}$ from individual 25 of family II when reacted with SAM94 gives 

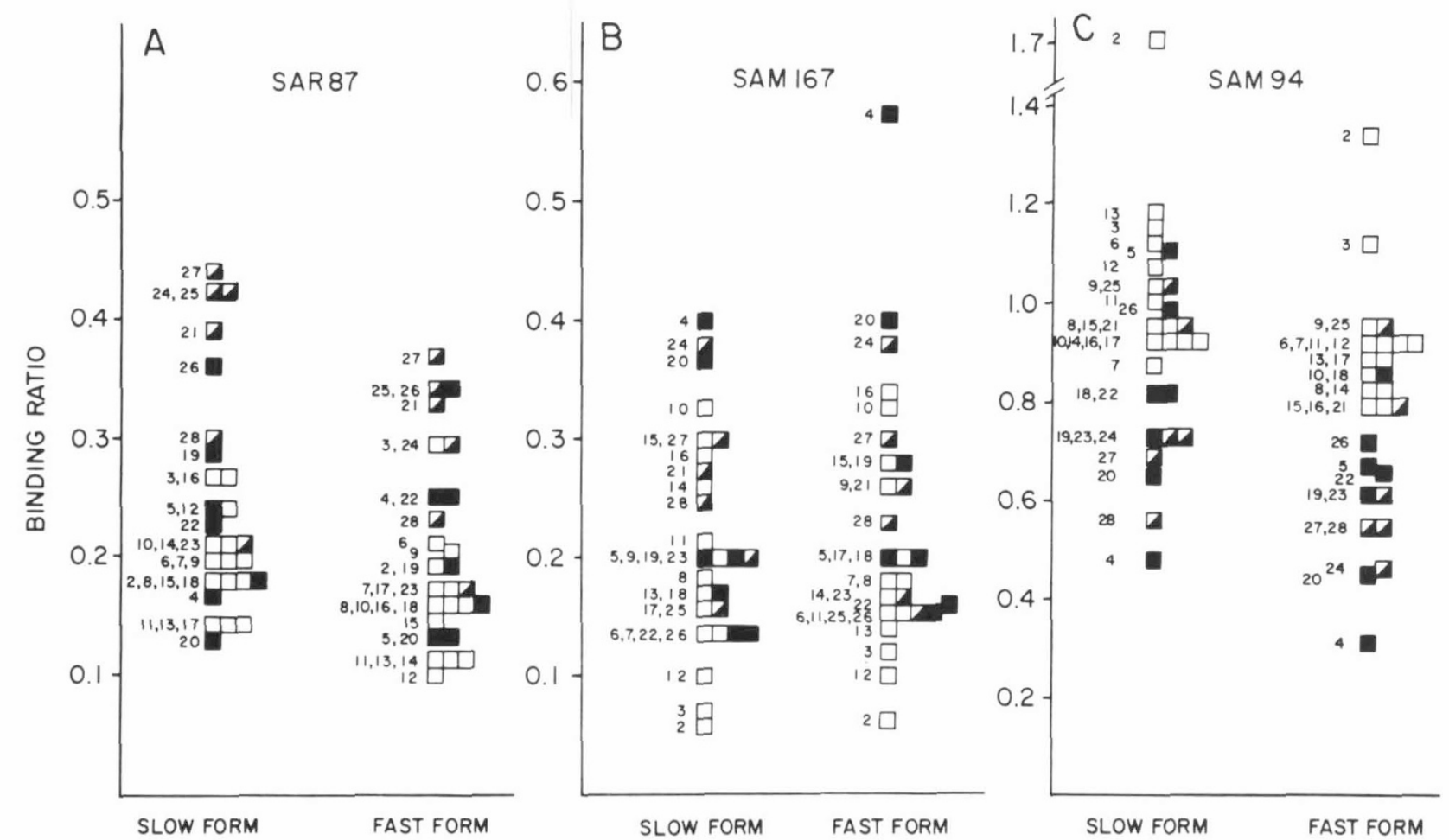

Fig. 4. Composite of monoclonal antibody binding patterns. Binding ratios of antibodies to slow native (untreated) and fast (methylaminetreated) forms of $\alpha_{2} \mathrm{M}$ from the plasma samples described in Table 1 are shown in this figure. Individuals of different genetic background are highlighted. Each square represents an individual; open squares, control individuals; solid squares, CF homozygotes and half-filled squares, CF family members whether obligate heterozygotes or not.

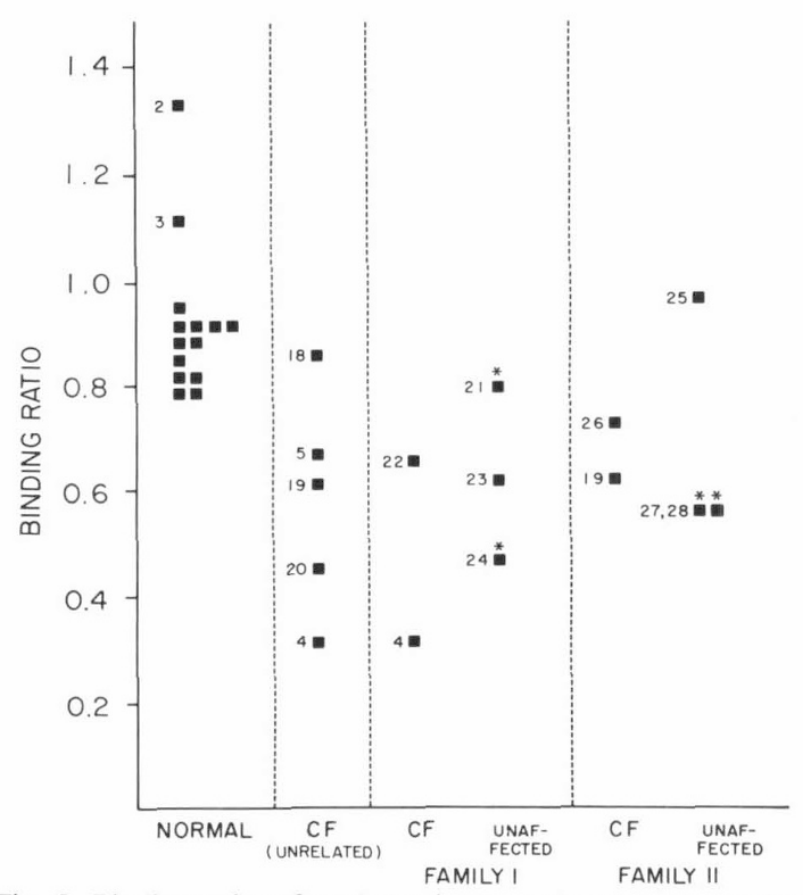

Fig. 5. Binding ratios of methylamine-treated $\alpha_{2} \mathrm{M}$ samples of families with the antibody SAM94. Graph shows the distribution of binding ratios of $\alpha_{2} \mathrm{M}$ samples when divided into categories based upon the genetic status. Family members from the two families tested are divided into those members affected with $\mathrm{CF}$ and those unaffected. Each square represents one individual; numbers to the left of the squares correspond to the sample number. Obligate heterozygotes are distinguished by an asterisk.

a binding ratio similar to those values calculated for normal $\alpha_{2} \mathrm{M}$ samples.

The variability of binding ratios to methylamine-treated cystic fibrosis $\alpha_{2} \mathrm{M}$ that we observe with antibody SAM94 may be accounted for by the heterogeneity in the disease (Table 1; Fig. 5). Examination of the five $\alpha_{2} \mathrm{M}$ samples from unrelated individuals with cystic fibrosis by binding of SAM94 shows that one gives a binding ratio similar to that of control individuals. In addition, we see a range of binding ratios for the remaining four unrelated samples. Medical treatment and age of the patients appear to have no effect on the results obtained. Since the frequency of CF heterozygotes in the general population is approximately 0.05 , we expect in our presumably normal sample of 12 controls $0.05 \times 12=0.6$, or about one individual carries the gene for cystic fibrosis. However, none of the normal $\alpha_{2} \mathrm{M}$ samples tested give binding ratios as low as the mean binding ratio of the $\mathrm{CF}$ samples.

\section{DISCUSSION}

The examination of purified human $\alpha_{2} \mathrm{M}$ with monoclonal anti- $\alpha_{2} \mathrm{M}$ antibodies has resulted in an interesting observation. When normal and cystic fibrosis $\alpha_{2} \mathrm{M}$ are reacted with monoclonal antibody SAM94, a lower level of binding is seen with the CF samples. When examining the nucleophile-treated form of $\alpha_{2} \mathrm{M}$ with antibody SAM94 under the same conditions, the decreased level of reactivity is more apparent. This decrease in antibody reactivity to $\mathrm{CF} \alpha_{2} \mathrm{M}$ in both the native form as well as with the nucleophile-treated protein is not observed when other anti- $\alpha_{2} \mathrm{M}$ monoclonal antibodies are used.

It has been hypothesized that structural alteration in $\mathrm{CF}$ plasma $\alpha_{2} \mathrm{M}$ is responsible for the presence of protease- $\alpha_{2} \mathrm{M}$ complexes and abnormal peptides. However, several reports do not support the idea that there is an abnormality in CF $\alpha_{2} \mathrm{M}$. The interaction of proteases with $\alpha_{2} \mathrm{M}$ did not demonstrate any difference with respect to protease binding ability in $\mathrm{CF} \alpha_{2} \mathrm{M}$ nor were the $\alpha_{2}$-macroglobulins distinguishable by isoelectric focusing $(18,20,21)$. The examination of the cleavage of subunits of $\alpha_{2} \mathrm{M}$ when reacted with trypsin showed similar electrophoretic patterns when purified $\alpha_{2} \mathrm{M}$ was passed over a column of trypsin immobilized on Sepharose (6). Recent reports indicate protease binding and structure of $\alpha_{2} \mathrm{M}$ in CF and controls are similar (5, 
$7,8,19)$. The use of monoclonal antibodies, however, allows the examination of a single antigenic determinant which if altered may have no detectable effect on the capacity to bind proteases or affect the mobility of the protein in electrophoresis. Monoclonal antibodies specific for the nucleophile-treated form of $\alpha_{2} \mathrm{M}$ have been identified (17).

Our antibody, SAM94, appears to detect an alteration in CF and CF heterozygote $\alpha_{2} \mathrm{M}$; this difference is enhanced when the protein is treated with methylamine. We hypothesize that this antibody identifies a determinant which has: 1) a decrease in frequency on the $\mathrm{CF} \alpha_{2} \mathrm{M}$ molecule, or 2) an alteration in the antigenic site thereby causing reduced affinity of the antibody for this site, or 3) a modification in the conformation of nucleophile-treated $\mathrm{CF} \alpha_{2} \mathrm{M}$. A report by Ben-Yoseph and colleagues $(3,4)$ indicates they have identified a decrease in glycosylation of $\mathrm{CF} \alpha_{2} \mathrm{M}$. Preliminary experiments of our own suggest that the antibody may be recognizing a determinant of carbohydrate origin.

A defect in the autoregulation of the monocytes and macrophages has been postulated by Wilson and Fudenberg (30). They report that $\alpha_{2} \mathrm{M}$ receptors on $\mathrm{CF}$ monocytes-macrophages are not abnormal, but that the defect resides in the $\alpha_{2} \mathrm{M}$ and subsequently results in the accumulation of $\mathrm{CF}$ factors. Our examination using SAM94 to study methylamine-treated $\alpha_{2} \mathrm{M}$ suggests a structural difference is present in the $\alpha_{2} \mathrm{M}$ from $\mathrm{CF}$ patients and $\mathrm{CF}$ obligate heterozygotes. Analysis of the relationship between the antigenic site of the molecule detected by SAM94 and the portion of the $\alpha_{2} \mathrm{M}$ interacting with the receptor may prove informative.

The CF patients and families that have been screened clearly indicate that antibody SAM94 is identifying a determinant present on the $\alpha_{2} \mathrm{M}$ of certain individuals. The differential binding to CF samples could possibly be due to the presence of a polymorphism unrealted to cystic fibrosis. Further screening of CF individuals and family members must be undertaken to test the reliability of the antibody for identifying those individuals carrying the gene for cystic fibrosis. The data do confirm the idea that monoclonal antibodies are useful for detecting subtle structural variations in macromolecules and that they can in fact be used to detect differences not easily identified by other methods.

Acknowledgments. The authors would like to thank Douglas Holsclaw and his staff for kindly supplying the CF plasma and plasma from family members and Chester Zmijewski for making the normal plasma available. In addition, we extend our thanks to Jerry Kaplan for providing the zinc chelate-Sepharose column material. We also would like to thank Harry Harris and Richard Spielman for their helpful discussions and critical review of the manuscript.

\section{REFERENCES}

1. Barrett AJ, Brown MA, Sayers CA 1979 The electrophoretically 'slow' and 'fast' forms of the $\alpha_{2}$-macroglobulin molecule. Biochem J 181:401

2. Barrett AJ, Starkey PM 1973 The interaction of $\alpha_{2}$-macroglobulin with proteinases: characteristics and specificity of the reaction and a hypothesis concerning its molecular mechanism. Biochem J 133:709

3. Ben-Yoseph Y, Defranco CL, Nadler HL 1979 Decreased sialic acid and altered binding to lectins of purified $\alpha_{2}$-macroglobulin from patients with cystic fibrosis. Clin Chim Acta 99:31

4. Ben-Yoseph Y, Defranco CL, Nadler HL 1980 Altered carbohydrate moiety in $\alpha_{2} \mathrm{M}$-macroglobulin purified from plasma of patients with cystic fibrosis.
In Sturgess JM (ed) Proceedings of the Eighth International Cystic Fibrosis Conference. Perspectives in Cystic Fibrosis. Canadian Cystic Fibrosis Foundation, Toronto $\mathrm{p} 4 \mathrm{a}$

5. Bridges MA, Applegarth DA, Johannson J, Wong LTK, Davidson AGF 1982 Protease binding by $\alpha_{2}$-macroglobulin in cystic fibrosis. Clin Chim Acta 118:33

6. Burdon MG 1980 Normal subunit cleavage of alpha-2-macroglobulin in cystic fibrosis. Clin Chim Acta 100:225

7. Bury AF, Barrett AJ 1982 Plasma arginine esterase in cystic fibrosis: Kinetics of activation, identification as plasma kallikrein, reaction with $\alpha_{2}$-macroglobulin and comparison with levels in normal plasma. Pediatr Res 16:613

8. Bury AF, Roberts RC 1982 Comparison of the polypeptide composition of cystic fibrosis plasma with normal plasma by high resolution electrophoresis. Clin Chim Acta 118:45

9. Eager KB, Kennett RH 1983 The use of conventional antisera in the production of specific monoclonal antibodies, J Immunol Methods 64:157

10. Hall PK, Roberts RC 1978 Physical and chemical properties of $\alpha_{2}$-macroglobulin. Biochem J 171:27

11. Harpel PC 1973 Studies on human plasma $\alpha_{2}$-macroglobulin-enzyme interactions: evidence for proteolytic modification of the subunit chain structure. $J$ Exp Med 138:508

12. Imber MJ, Pizzo SV 1981 Clearance and binding of two electrophoretic "fast" forms of human $\alpha_{2}$-macroglobulin. J Biol Chem 256:8134

13. Kennett RH, Denis KA, Tung AS, Klinman N 1978 Hybrid plasmacytoma production: fusions with adult spleen cells, monoclonal spleen fragments, neonatal spleen cells and human spleen cells. Curr Top Microbiol Immunol $81: 77$

14. Kohler G, Milstein C 1975 Continuous culture of fused cells secreting antibody of predefined specificity. Nature 256:495

15. Kurecki T, Kress LF, Laskowski M 1979 Purification of human plasma $\alpha_{2}{ }^{-}$ macroglobulin and $\alpha$ 1-proteinase inhibitor using zinc chelate chromatography. Anal Biochem 99:415

16. Laurell C-B, Jeppsson J-O 1975 Protease inhibitors in plasma. In: Putnam FW (ed) The Plasma Proteins: Structure, Function and Genetic Control. Academic Press, New York, vol 1:229-264

17. Marynen P, VanLeuven F, Cassiman J-J, Van den Berghe H 1981 A monoclonal antibody to a neo-antigen on $\alpha_{2}$-macroglobulin complexes inhibits receptor-mediated endocytosis. J Immunol 127:1782

18. Parsons M, Romeo G 1980 Cystic fibrosis $\alpha_{2}$-macroglobulin protease interaction in vitro. Clin Chim Acta 100:215

19. Roberts RC, Nelles LP, Hall PK, Salvesen GS, Mischler E 1982 Comparison of the structure and aspects of the proteinase-binding properties of cystic fibrosis $\alpha_{2}$-macroglobulin and normal $\alpha_{2}$-macroglobulin. Pediatr Res 16:416

20. Romeo G, Denaro M. Parsons M 1980 Competition for trypsin binding between $\alpha_{2}$-macroglobulin and antitrypsin antibodies in cystic fibrosis. J Lab Clin Med 95:116

21. Schidlow DF, Kueppers F 1980 Trypsin binding activity of alpha-2-macroglobulin in cystic fibrosis and other lung diseases. Am Rev Resp Dis 121:31

22. Shapira E, Ben-Yoseph Y, Nadler HL 1976 Decreased formation of $\alpha_{2} \mathrm{M}$ protease complexes in plasma of patients with cystic fibrosis. Biochem Biophys Res Commun 71:864

23. Shapira E, Ben-Yoseph Y. Nadler HL 1977 Abnormal breakdown of $\alpha_{2-}$ macroglobulin-trypsin complex in cystic fibrosis. Clin Chim Acta 78:359

24. Shapira E, Martin CL, Nadler HL 1977 Comparison between purified $\alpha_{2 *}$ macroglobulin preparations from normal controls and patients with cystic fibrosis. J Biol Chem 252:7923

25. Shapira E, Rao GJS. Wessel HU, Nadler HL 1976 Absence of an $\alpha_{2}$-macroglobulin-protease complex in cystic fibrosis. Pediatr Res 10:812

26. Shulman M, Wilde CD, Kohler G 1978 A better cell line for making hybridomas secreting specific antibodies. Nature 276:269

27. Starkey PM, Barrett AJ 1977 Alpha-2-macroglobulin, a physiological regulator of proteinase activity. In: Barrett AJ (ed) Proteinases in Mammalian Cells and Tissues. Elsevier/North Holland, Amsterdam, pp 663-696

28. Talamo RC, Rosenstein BJ, Berninger RW 1983 Cystic Fibrosis. In: Stanbury JB. Wyngaarden JB. Fredrickson DS, Goldstein JL. Brown MS (eds) The Metabolic Basis of Inherited Disease, ed 5. McGraw-Hill, New York, p 1889

29. Wilson GB, Fudenberg HH 1976 Studies on cystic fibrosis using isoelectric focusing. II. Demonstration of deficient proteolytic cleavage of $\alpha_{2}$-macroglobulin in cystic fibrosis plasma. Pediatr Res 10:87

30. Wilson GB, Fudenberg HH 1982 Does a primary host defense abnormality involving monocytes-macrophages underlie the pathogenesis of lung disease in cystic fibrosis? Med Hypotheses 8:527

31. Zais DP, Roberts RC 1977 System for simplified discontinuous-gradient polyacrylamide-gel electrophoresis. Clin Chem 23:590 